\title{
Assessing the impact of a future volcanic eruption on decadal predictions
}

\author{
Sebastian Illing ${ }^{1}$, Christopher Kadow ${ }^{1}$, Holger Pohlmann ${ }^{2}$, and Claudia Timmreck ${ }^{2}$ \\ ${ }^{1}$ Freie Universität Berlin, Institute of Meteorology, Berlin, Germany \\ ${ }^{2}$ Max Planck Institute for Meteorology, Hamburg, Germany \\ Correspondence: Sebastian Illing (sebastian.illing@met.fu-berlin.de)
}

Received: 22 January 2018 - Discussion started: 2 February 2018

Accepted: 27 April 2018 - Published: 6 June 2018

\begin{abstract}
The likelihood of a large volcanic eruption in the future provides the largest uncertainty concerning the evolution of the climate system on the timescale of a few years, but also an excellent opportunity to learn about the behavior of the climate system, and our models thereof. So the following question emerges: how predictable is the response of the climate system to future eruptions? By this we mean to what extent will the volcanic perturbation affect decadal climate predictions and how does the pre-eruption climate state influence the impact of the volcanic signal on the predictions? To address these questions, we performed decadal forecasts with the MiKlip prediction system, which is based on the MPI-ESM, in the low-resolution configuration for the initialization years 2012 and 2014, which differ in the Pacific Decadal Oscillation (PDO) and North Atlantic Oscillation (NAO) phase. Each forecast contains an artificial Pinatubo-like eruption starting in June of the first prediction year and consists of 10 ensemble members. For the construction of the aerosol radiative forcing, we used the global aerosol model ECHAM5-HAM in a version adapted for volcanic eruptions. We investigate the response of different climate variables, including near-surface air temperature, precipitation, frost days, and sea ice area fraction. Our results show that the average global cooling response over 4 years of about $0.2 \mathrm{~K}$ and the precipitation decrease of about $0.025 \mathrm{~mm} \mathrm{day}^{-1}$ is relatively robust throughout the different experiments and seemingly independent of the initialization state. However, on a regional scale, we find substantial differences between the initializations. The cooling effect in the North Atlantic and Europe lasts longer and the Arctic sea ice increase is stronger in the simulations initialized in 2014. In contrast, the forecast initialized in 2012 with a negative PDO shows a prolonged cooling in the North Pacific basin.
\end{abstract}

\section{Introduction}

More and more attention has been paid to decadal climate prediction in the last decade (Meehl et al., 2009; Smith et al., 2007). This research field tries to fill the gap between shortterm (weather to seasonal) predictions on the one hand and long-term climate projections on the other hand. Decadal predictability comes mainly from the multi-year memory of the ocean. The memory in the ocean arises, for instance, from the persistence of ocean heat content anomalies and from properly initialized ocean dynamics and circulation (e.g., Guemas et al., 2012; Matei et al., 2012). A detailed explanation of the principles behind decadal prediction can be found in Kirtman et al. (2013).
A number of studies revealed that there is at least potential prediction skill in near-surface air temperature, precipitation, and three-dimensional variables like air temperature or geopotential height (Goddard et al., 2013; Kadow et al., 2016; Stolzenberger et al., 2016). Recently, some institutions like the UK Met Office and the German project for decadal climate prediction, MiKlip (Marotzke et al., 2016), have started issuing decadal climate forecasts for near-surface air temperature on a regular - but still experimental - basis (metoffice.gov, 2017; Smith et al., 2013; Vamborg et al., 2017).

The skill of decadal predictions is usually evaluated using hindcast simulations (e.g., Doblas-Reyes et al., 2013; 
Kim et al., 2012), and it is assumed that external forcing is known over the whole simulation period. In a real decadal forecast, this assumption is invalid because rapid forcing changes like volcanic eruptions cannot be predicted in advance. Hence, strong tropical volcanic eruptions (SVEs) are arguably the largest source of uncertainty for this type of prediction. They increase the stratospheric aerosol load, which leads to a reduction of global mean surface temperature due to the reduced incoming solar radiation. For instance, after the tropical Pinatubo eruption in 1991, a global peak cooling of about $0.4 \mathrm{~K}$ (Thompson et al., 2009) was observed. Regionally, however, warm anomalies are found after SVEs, e.g., the winter warming over Europe in the first two winters after the eruption (Kirchner et al., 1999; Robock and Mao, 1992). Apart from temperature, SVEs also have an impact on atmospheric composition, atmosphere and ocean dynamics, and the hydrological cycle (e.g., Robock, 2000; Timmreck, 2012). The major volcanic eruptions that occurred since 1850 were followed by a period of reduced global precipitation (Robock and Mao, 1992; Gu and Adler, 2011; Iles and Hegerl, 2014), and volcanoes can also modulate the African, Asian and South American monsoon systems (e.g., Joseph and Zeng, 2011; Iles and Hegerl, 2013; Liu et al., 2016). Sea ice in the Northern Hemisphere is also affected by large volcanic eruptions that occurred between 1850 and 2005, and SVEs can cause up to a decade of increased Arctic sea ice extent (Ding et al., 2014; Gagné et al., 2017). Gagné et al. (2017), for example, demonstrated that the sea ice response to SVEs is dependent on pre-eruption temperature conditions with a warmer pre-eruption climate leading to a stronger sea ice response. There is some evidence from observations and reconstructions that SVEs lead to a positive phase of the Northern Atlantic Oscillation (NAO) in the first few winters following the eruption (e.g., Ortega et al., 2015; Swingedouw et al., 2017), but recent model studies suggest that this signal might not be that robust (Bittner et al., 2016; Ménégoz et al., 2017). It has also been suggested that the positive NAO response could be better interpreted in terms of a deficit of negative NAO circulations (Toohey et al., 2014).

There are only a few studies that focus on how volcanic forcing impacts decadal climate predictions. Meehl et al. (2015) showed in a multi-model study that the Pinatubo eruption led to a reduction of decadal hindcast skill in Pacific sea surface temperatures. Timmreck et al. (2016) demonstrated that neglecting volcanic aerosol in decadal predictions significantly affects hindcast skill for near-surface air temperature and leads to a skill reduction in most regions up to prediction year 5. Bethke et al. (2017) explored how possible future volcanic eruptions impact climate variability under RCP4.5 and found that the consideration of volcanic forcing enhances climate variability on annual to decadal timescales. However, not every volcanic eruption influences the climate in the same way. Zanchettin et al. (2013) showed in a case study of the Tambora eruption in 1815 that near-surface atmospheric and oceanic dynamics are significantly influ- enced by climate background conditions. Furthermore, hindcasts with the atmosphere-only HADGEM1 model (Marshall et al., 2009) showed that the climate anomalies in the first post-volcanic winter over Europe are strongly dependent on the stratospheric conditions in early winter.

Historically explosive tropical volcanic eruptions have a statistical recurrence frequency of about 50 to 100 years (Ammann and Naveau, 2003; Self et al., 2006). With the Pinatubo eruption almost 27 years ago and the recent ongoing unrest of Mount Agung in Indonesia, the following question arises: what would happen if a large volcanic eruption occurred in the present and how dependent would the results be on the start year and the associated initial climate state? In this paper, we investigate the response of different climate variables, including near-surface air temperature (TAS), precipitation (PR), number of frost days (FD), and sea ice area fraction (SIC), to an artificial Pinatubo-like eruption happening in June of the first simulation year for two initializations that differ in their initial state. To quantify the volcanic effect we compare our multi-year forecasts with the simulations without a volcanic eruption performed with the MiKlip prediction system (Pohlmann et al., 2013).

In Sect. 2 we describe the models used and our experimental setup, while the results of our analysis for different variables are presented in Sect. 3. In Sect. 4 we draw conclusions and discuss our results.

\section{Model description and experimental setup}

\subsection{Model description}

We perform our forecasts containing a Pinatubo-like eruption with the baseline1 version of the MiKlip prediction system (Marotzke et al., 2016; Pohlmann et al., 2013), which is based on the coupled Max Planck Institute-Earth System Model (MPI-ESM; Giorgetta et al., 2013; Jungclaus et al., 2013). The MPI-ESM is an Earth system model with atmosphere, ocean, and dynamic vegetation components. We use the "low-resolution" (LR) configuration of the baseline1 system, which has a resolution of T63 with 47 vertical levels in the atmosphere and an oceanic resolution of $1.5^{\circ}$ with 40 vertical levels. The atmospheric component ECHAM6 (Stevens et al., 2013) is initialized with full fields of temperature, vorticity, divergence, and sea level pressure from the ECMWF atmosphere reanalysis (Dee et al., 2011). The oceanic component MPI-OM (Jungclaus et al., 2013) is initialized using anomaly fields from the ECMWF ocean reanalysis system 4 (Balmaseda et al., 2013) including temperature and salinity. For decadal forecasting, an operational model system for the rapid model-based assessment of the decadal-scale climate impact is needed in the case of any major volcanic eruption. However, any modification to the climate model itself requires a retuning (Mauritsen et al., 2012), a new control run with constant forcing to make sure the model simulates a stable climate, and a new ensemble of historical runs as 

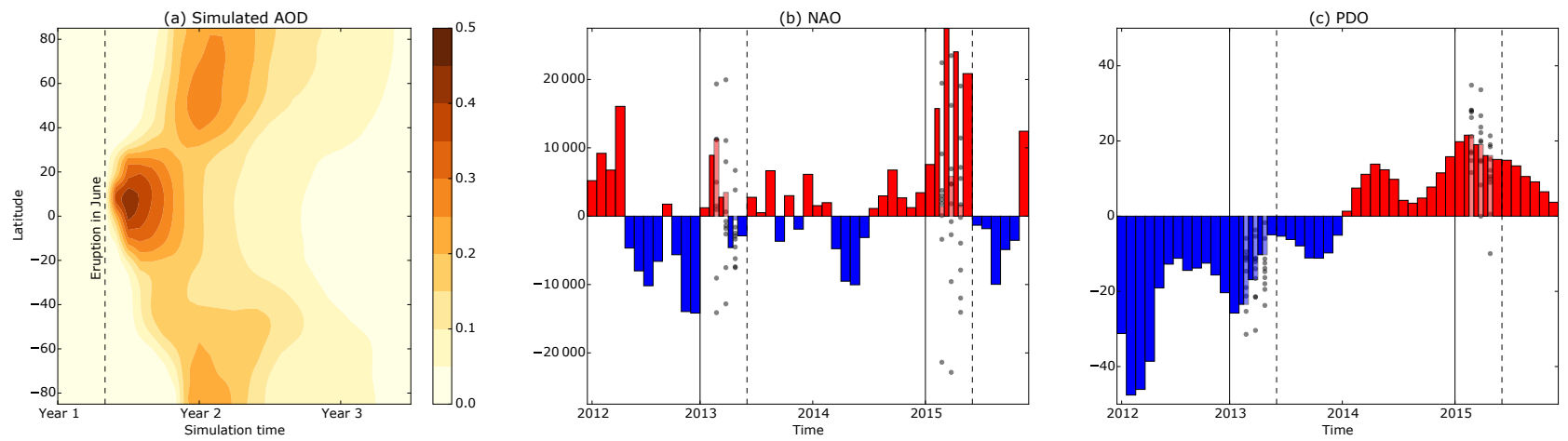

Figure 1. (a) Temporal evolution of the stratospheric aerosol optical depth (AOD) used for our simulations with a Pinatubo-like eruption. The climate indices NAO (b) and PDO (c) calculated from the assimilation model run. Lighter colors are the indices of the prediction system ensemble mean before the Pinatubo-like eruption and grey circles are the individual ensemble members. Vertical lines indicate the initialization time of our forecast experiments and vertical hatched lines indicate the start of the Pinatubo-like eruption.

a reference for assessing skill enhancement through initialization (Goddard et al., 2013; Illing et al., 2014).

Here, a two-step modeling approach is applied to consider the effect of large volcanic eruptions in the MiKlip decadal prediction system. In a first step, the formation of volcanic sulfate aerosol and its corresponding optical parameters (aerosol optical depth: AOD; effective radius: $\mathrm{R}_{\mathrm{eff}}$ ) are calculated from the initial stratospheric $\mathrm{SO}_{2}$ injection with a global stratospheric aerosol model. In a second step, AOD and $R_{\text {eff }}$ are used as monthly mean forcing in the decadal prediction system.

For the construction of the aerosol radiative forcing, we use the global aerosol model ECHAM5-HAM (Stier et al., 2005 ) in a version adapted for volcanic studies (Niemeier et al., 2009), which agrees very well with measurements of AOD in the visible range and the effective particle radius after the Pinatubo eruption. We decided to simulate a future Pinatubo-like eruption because the Pinatubo eruption is the best-observed eruption in recorded history and the second strongest since 1850. In addition, the likelihood of such an eruption is of the order of once every 50 to 100 years (e.g., Self, 2006). To compile volcanic forcing fields, we inject 17 MT $\mathrm{SO}_{2}$ over $3 \mathrm{~h}$ at the geographical location of Pinatubo $\left(15^{\circ} \mathrm{N}, 120^{\circ} \mathrm{E}\right)$ into the stratosphere (around $30 \mathrm{hPa}$ ). The simulated AOD field unsurprisingly resembles the observed pattern after the Pinatubo eruption (Fig. 1a).

\subsection{Experimental setup}

Figure 1a shows the aerosol optical depth (AOD) simulated with the global aerosol model for a Pinatubo-like volcanic eruption. We use the simulated AOD as the forcing component for the decadal prediction system. For our experiment, we perform two decadal forecasts for 10 years with 10 ensemble members each. For ensemble generation we use the lagged-day initialization method, which means that the individual ensemble member is started on different days around
31 December to spread the ensemble. One forecast was initialized around 31 December 2012 (Pinatubo-2012) and the other one around 31 December 2014 (Pinatubo-2014). The Pinatubo-like eruption happens in June of the first prediction year, which is June 2013 in the case of the Pinatubo-2012 experiment and June 2015 for the Pinatubo-2014 experiment. We chose these initialization years because they are relatively close together and therefore have similar greenhouse gas forcing that can be considered close to present day conditions, but they also differ in important climatic conditions. In December 2012 the Pacific Decadal Oscillation (PDO) and the North Atlantic Oscillation (NAO) were in a negative phase, whereas the Pinatubo-2014 experiment is initialized with a positive PDO and a positive NAO (Fig. $1 \mathrm{~b}$ and c). Other important climate modes like the El Niño-Southern Oscillation (ENSO) or the Atlantic Multidecadal Oscillation (AMO) are in a similar state in both experiments (not shown). PDO and NAO are both important drivers of internal climate variability. A negative PDO phase is associated with below average temperatures in the Pacific Northwest, British Columbia, and Alaska and an above average Indian summer monsoon (e.g., Mantua and Hare, 2002). A positive NAO indicates colder and drier Mediterranean regions and warmer and wetter than average conditions in northern Europe and the eastern United States (e.g., Visbeck et al., 2001). The different phases of the NAO and PDO at initialization time enables us to investigate the influence of initial climate conditions on the volcanic response of the model in a present day setup. As reference datasets, we use the MiKlip baseline1 experiments initialized on the same start dates (b1-2012 and b1-2014) but without volcanic aerosol.

In order to quantify the effect of volcanic aerosols, we calculate the differences in the ensemble mean between the simulations containing a Pinatubo-like eruption and the baseline1 simulations (exp-2012 is Pinatubo-2012 minus b12012, exp-2014 is Pinatubo-2014 minus b1-2014). We also calculate the difference between exp-2012 and exp-2014 to 
Initialized 2012

Global
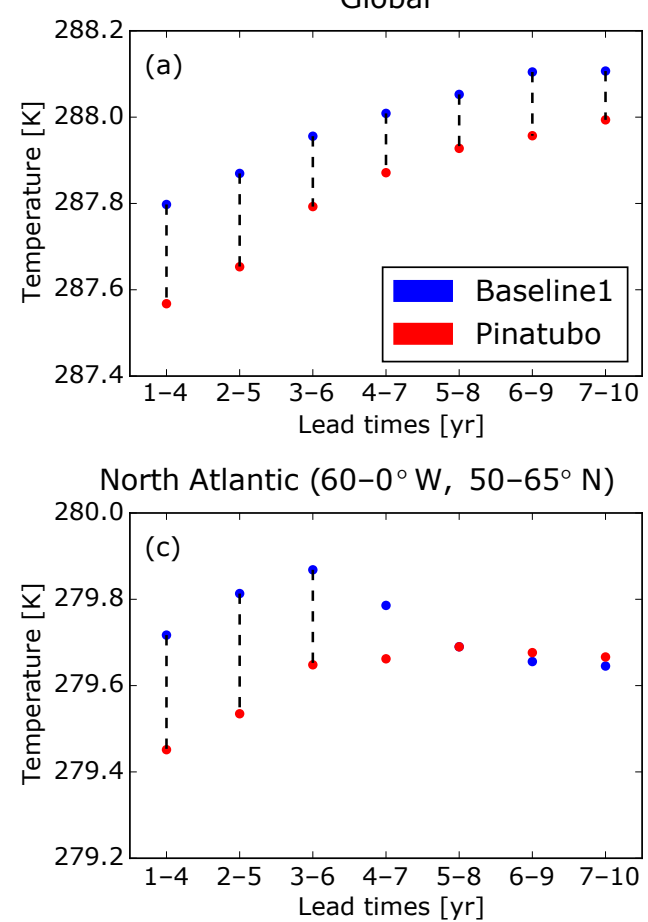

Europe $\left(10^{\circ} \mathrm{W}-35^{\circ} \mathrm{E}, 30-75^{\circ} \mathrm{N}\right)$

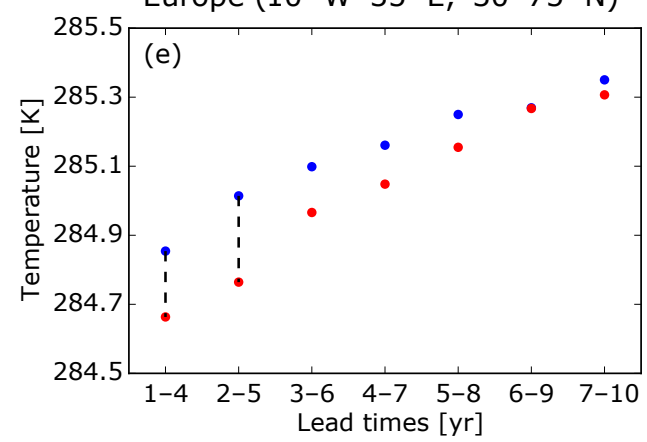

Initialized 2014

Global
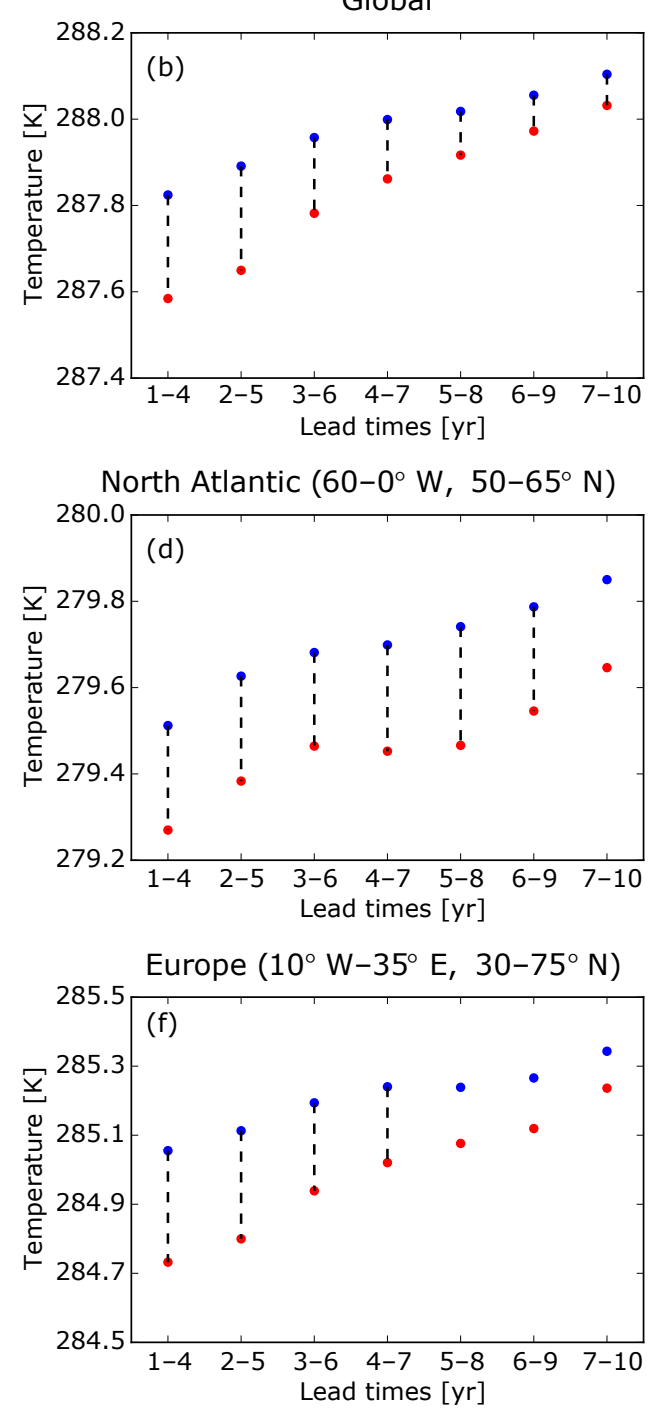

North Pacific basin $\left(130-250^{\circ} \mathrm{E}, 20-60^{\circ} \mathrm{N}\right)$ North Pacific basin $\left(130-250^{\circ} \mathrm{E}, 20-60^{\circ} \mathrm{N}\right)$
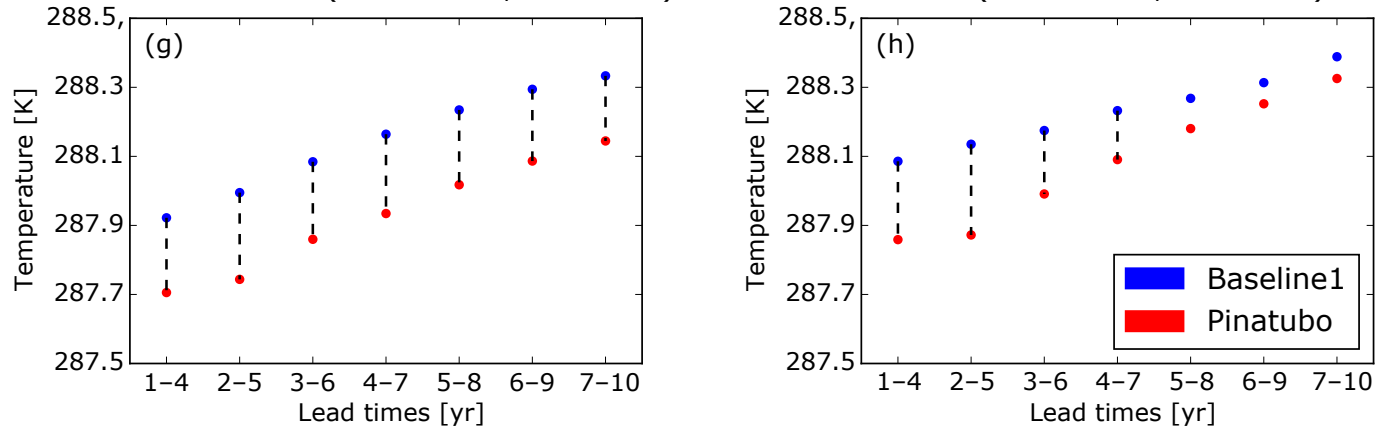

Figure 2. Time series of 4-year running mean ensemble forecast of near-surface air temperature (TAS) anomalies. The blue shows values without volcanic eruption, and red with a Pinatubo-like eruption. (a, c, e, g) Experiments initialized in 2012 and (b, d, f, h) those initialized in 2014. (a, b) Global mean, (c, d) North Atlantic $\left(60^{\circ} \mathrm{W}-0^{\circ} \mathrm{E}, 50-65^{\circ} \mathrm{N}\right)$, (e, f) Europe $\left(10^{\circ} \mathrm{W}-35^{\circ} \mathrm{E}, 30-75^{\circ} \mathrm{N}\right)$, and $(\mathbf{g}, \mathbf{h}) \mathrm{North}$ Pacific basin $\left(130-250^{\circ} \mathrm{E}, 20-60^{\circ} \mathrm{N}\right)$. Dashed lines indicate significant differences between the values at the $5 \%$ level. 
quantify the impact of the different initial conditions. Statistical significance is determined by using a two-sided $t$ test (Wilks, 2011).

\section{Results}

\subsection{Air temperature}

Figure 2 shows a forecast for the 4-year running mean nearsurface air temperature (TAS) for different regions. The forecast is shown like it would be issued by the MiKlip project (Vamborg et al., 2017). In addition, we present it together with our Pinatubo experiments. The Pinatubo-like eruption leads to a statistically significant decrease at the $95 \%$ level in global mean temperature of about $0.2 \mathrm{~K}$ on average in prediction years 1-4 in both experiments. The temperature difference gets smaller in later years, but is significant until prediction years 7-10 (Fig. 2a and b). Globally, there is no evident difference between the two experiments. The situation is different in the North Atlantic (NA; Fig. 2c and d). In the first prediction years, the volcanic aerosol leads to a temperature decrease of about $0.3 \mathrm{~K}$ in both experiments. However, in the 2012 experiments, the temperature difference decreases in prediction years 4-7 and completely vanishes from years 5-8. This adjustment is mainly because the b1-2012 experiment shows a negative trend in later prediction years and this negative temperature trend is not evident in the Pinatubo2012 experiment. In contrast, Fig. 2 d shows a constant temperature difference between b1-2014 and Pinatubo-2014 for the whole prediction period. For Europe (Fig. 2e and f) both initialization dates show a significant surface cooling in the Pinatubo experiments in years 1-4 and 2-5, but the cooling is more pronounced and stays significant longer until years 47 in the 2014 model runs. The difference between the two initialization dates 2012 and 2014 is strongest in the Northern Hemispheric spring and fall (not shown). In 2012 there is no significant temperature decrease in spring and fall visible due to the Pinatubo-like eruption, whereas the Pinatubo2014 simulation shows significant temperature drops of up to $0.4 \mathrm{~K}$ on average. In the North Pacific basin (Fig. $2 \mathrm{~g}$ and h) where the PDO index is calculated, both experiments show a temperature drop induced by the Pinatubo-like eruption in the first prediction years with the strongest values in prediction years 2-5. However, in the 2012 experiment, which is initialized with a negative PDO, the temperature difference stays nearly constant and significant over the whole prediction period, while in Pinatubo-2014 TAS starts recovering in prediction years 3-6.

This disparity is also visible in the global maps in Fig. 3, which shows TAS for prediction years 1-4 and 7-10. For both initialization dates, the Pinatubo-like eruption leads to significant cooling over most parts of the tropics, North America, and the North Atlantic (Fig. 3a and c) for prediction years 1-4. Generally, the cooling effect is strongest over the continents and reaches up to $1 \mathrm{~K}$ over North America.
We found the most substantial differences between the initialization dates in Europe, Siberia, and East Asia (Fig. 3e). In Scandinavia the earlier initialized run shows a slightly positive effect, whereas the latter one shows a strong cooling. Thus, the simulations started with the initial conditions of 2014 (e.g., positive PDO and NAO) react more strongly to stratospheric aerosols released by the Pinatubolike eruption in these regions. In contrast, exp-2012 shows a significantly stronger cooling over Alaska. The negative PDO phase results in a reduced advection, which means less warm air being advected from the North Pacific into this region, a transport which is especially important if solar radiation is weakened (Wendler, 2012). In later simulation years, the cooling effect is less pronounced in both experiments (Fig. 3b, d, and f). In exp-2012 some parts of the tropics are still significantly cooler, and in the North Pacific a significant negative horseshoe pattern is evident. This pattern is missing in the 2014 initialized runs, but there we have strong significant cooling over northern Canada, Arctic Siberia, and the North Atlantic. This finding is in alignment with Fig. $2 \mathrm{f}$ in which the cooling in the North Atlantic is persistent throughout the whole simulation period.

Figure 4 shows a cross section of the zonal mean air temperature (TA) averaged over prediction years $1-4$. In both experiments, the cooling we found at the surface continues in the troposphere and is strongest in the tropical troposphere between 100 and $400 \mathrm{hPa}$. Exp-2014 shows a warming in the upper troposphere at $100 \mathrm{hPa}$ in the northern polar region, whereas exp-2012 shows a slight cooling in this region. In the lower stratosphere, the Pinatubo-like eruption leads to a warming of up to $1.4 \mathrm{~K}$ in both experiments. This warming is due to the absorption of solar near-IR radiation by the increased sulfate aerosol formed after the eruption (e.g., Houghton et al., 1996; Stenchikov et al., 1998).

\subsection{Sea ice}

Gagne et al. (2017) recently showed that a decade of increased Arctic sea ice followed the last three large volcanic eruptions in the 20th century. Figure 5 shows the differences in the ensemble mean forecasts of sea ice area fraction (SIC) for prediction years 1-4 for the sea ice maximum in March (top row) and the sea ice minimum in September (bottom row). Overall we see increased maximum values of SIC due to the volcanic eruption in both experiments, but the two initialization times differ in the affected local areas. On the one hand, exp-2012 shows increased values of SIC in the Bering Sea of up to $10 \%$ where there is no evident signal in exp-2014. On the other hand, the 2014 initialized experiment shows significantly increased SIC values in the Nordic Sea where the sea ice area fraction of exp-2012 is only slightly higher. This different behavior is not only evident in the first four prediction years. Figure 6a-d show the 4year running mean forecast for maximum SIC in the Nordic Sea area $\left(30-90^{\circ}\right.$ E, $\left.70-85^{\circ} \mathrm{N}\right)$ and in the Bering Sea (165- 
(a)

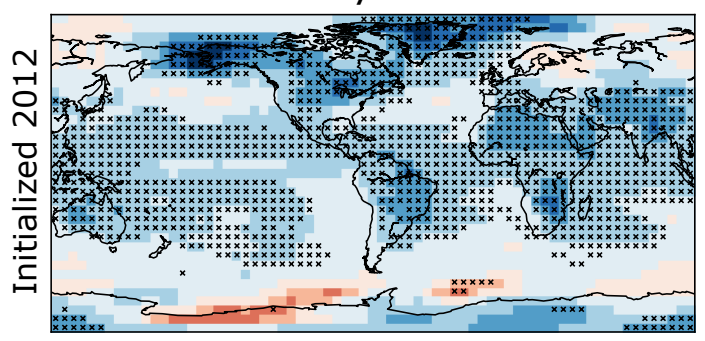

(c)

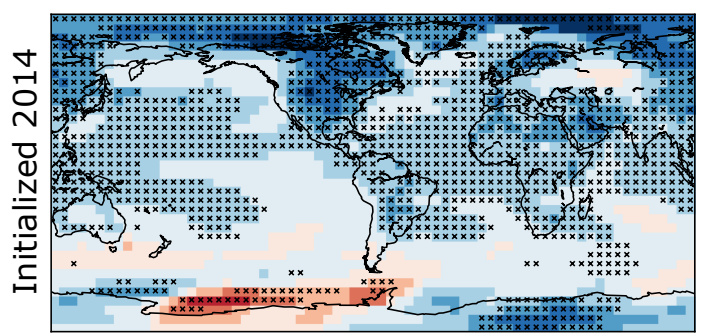

(e)

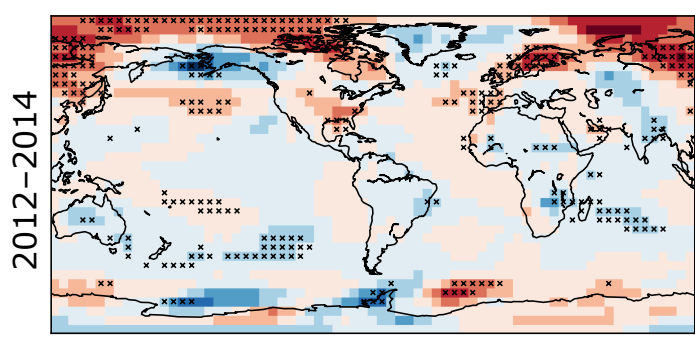

(b)

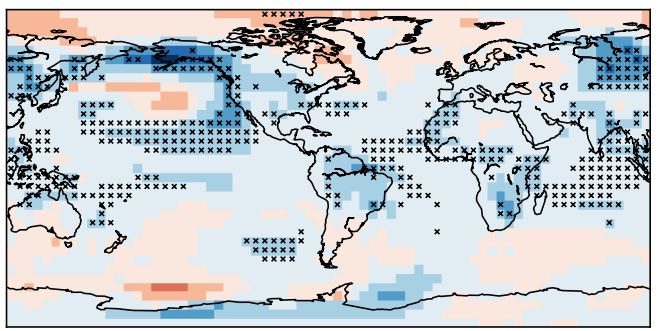

(d)

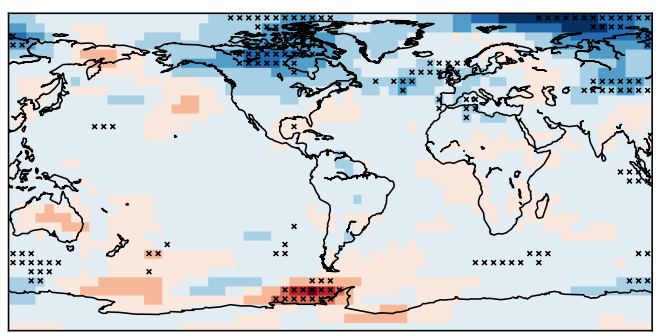

(f)

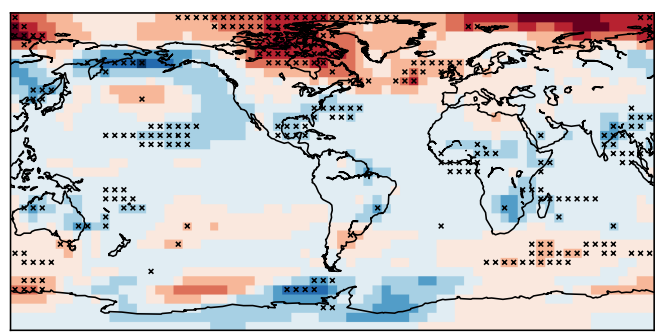

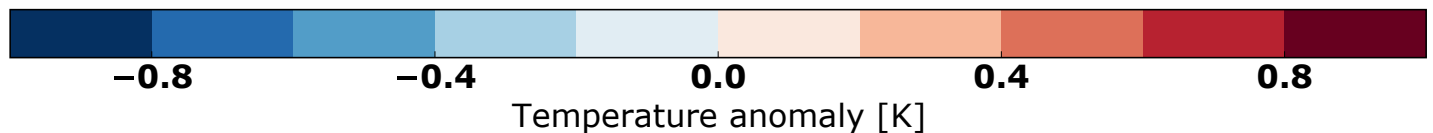

Figure 3. Differences in ensemble mean forecasts of TAS for prediction years 1-4 (a, c, e) and 7-10 (b, d, f). Top row (a, b) shows exp2012 (Pinatubo-2012 - b1-2012), middle row (c, d) shows exp-2014 (Pinatubo-2014 - b1-2014), and bottom row (e, f) shows the difference between the two upper (exp-2012 - exp-2014). Crosses denote values significantly different from zero exceeding a $5 \%$ level.
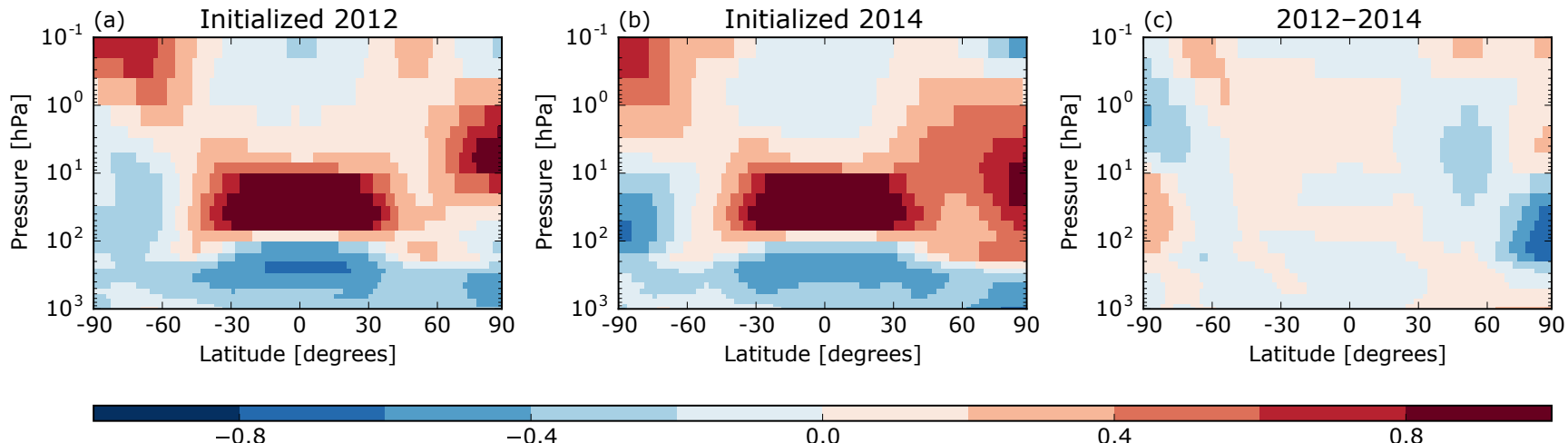

$-0.4$

0.0

Temperature anomaly $[\mathrm{K}]$

Figure 4. Differences in ensemble mean forecasts of zonal mean air temperature (TA) for prediction years 1-4. (a) Exp-2012 (Pinatubo-2012 - b1-2012), (b) exp-2014 (Pinatubo-2014 - b1-2014), and (c) the difference between the two (exp-2012 - exp-2014). 

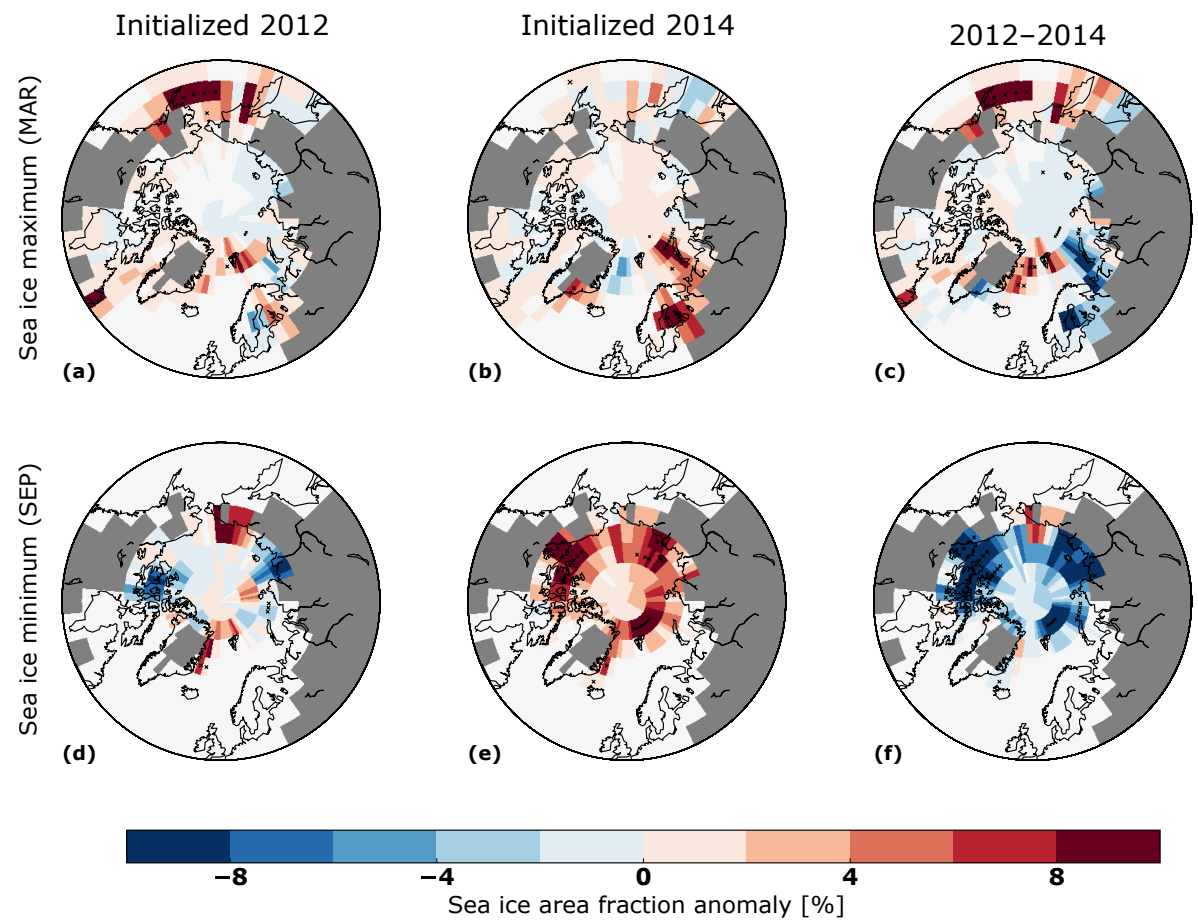

Figure 5. Differences in ensemble mean forecasts of SIC for prediction years 1-4, (a-c) for the 4-year mean maximum in March, and (d-f) for the 4-year mean minimum in September. (a, d) Exp-2012 (Pinatubo-2012 - b1-2012), (b, e) exp-2014 (Pinatubo-2014 - b1-2014), and (c, f) the difference between the two (exp-2012 - exp-2014). Crosses denote values significantly different from zero exceeding a $5 \%$ level.
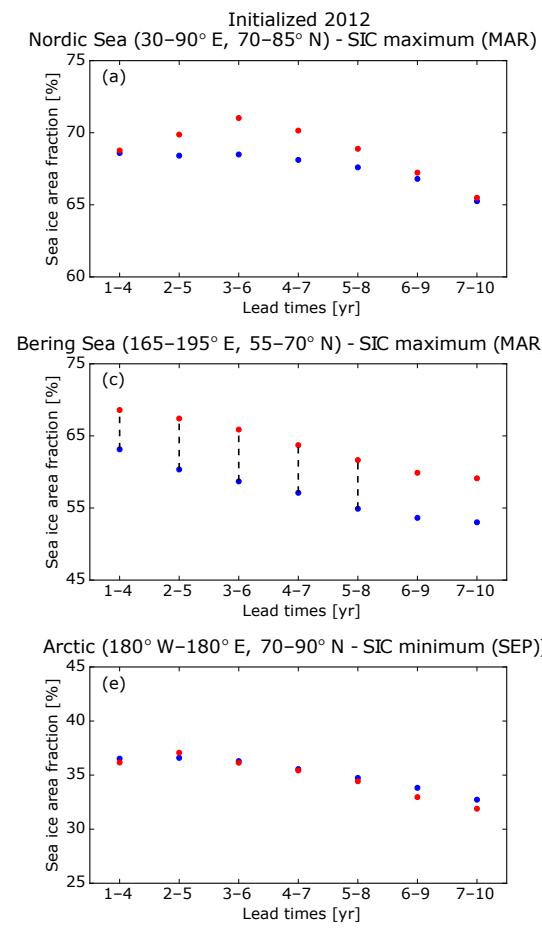

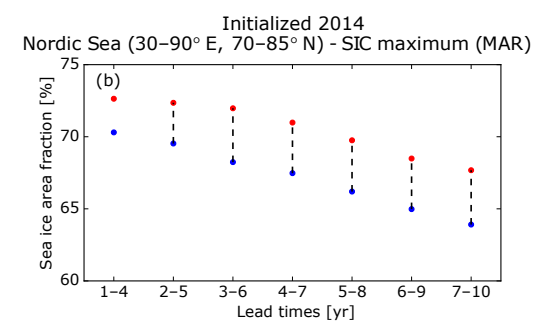

Bering Sea $\left(165-195^{\circ} \mathrm{E}, 55-70^{\circ} \mathrm{N}\right)$ - SIC maximum (MAR)
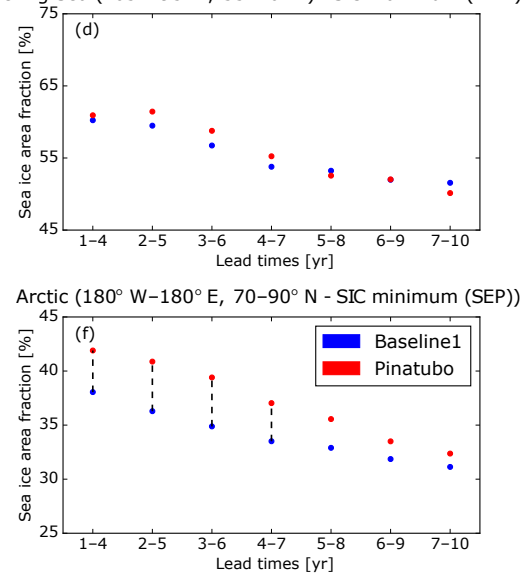

Figure 6. Same as Fig. 2, but for sea ice area fraction (SIC) maximum and minimum and different regions. (a, b) Nordic Sea (30-90 E, $\left.70-85^{\circ} \mathrm{N}\right),(\mathbf{c}, \mathbf{d})$ Bering Sea $\left(165-195^{\circ} \mathrm{E}, 55-70^{\circ} \mathrm{N}\right)$, and $(\mathbf{e}, \mathbf{f})$ the Arctic $\left(180^{\circ} \mathrm{W}-180^{\circ} \mathrm{E}, 70-90^{\circ} \mathrm{N}\right)$. Dashed lines indicate significant differences between the values at the $5 \%$ level. 
(a)

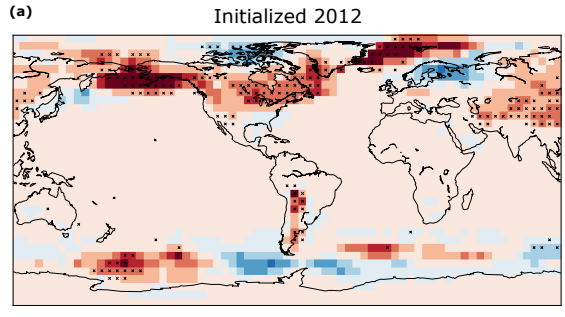

(b)

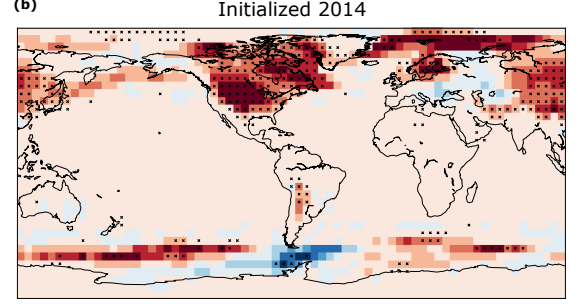

(c) 2012-2014

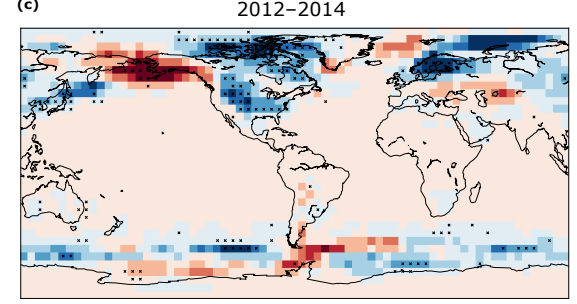

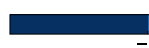
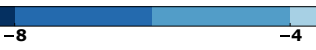

Frost day anomaly per year

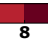

Figure 7. Differences in ensemble mean forecasts of frost days (FDs) for prediction years 1-4. (a) Exp-2012 (Pinatubo-2012 - b1-2012), (b) exp-2014 (Pinatubo-2014 - b1-2014), and (c) the difference between the two (exp-2012 - exp-2014). Crosses denote values significantly different from zero exceeding a $5 \%$ level.

$\left.195^{\circ} \mathrm{E}, 55-70^{\circ} \mathrm{N}\right)$. The experiment initialized in 2014 reacts more strongly to the Pinatubo like eruption in the Nordic Sea and has significantly increased maximum SIC values over the whole prediction period. On the other hand, the 2014 initialization shows nearly no response to the volcanic aerosol in the Bering Sea, whereas the Pinatubo-2012 experiment has increased SIC over the whole forecast period with significant values up to prediction years $5-8$. The stronger response in the Bering Sea in the 2012 experiment could be explained by the negative values of the PDO index bringing colder temperatures to Alaska (Overland et al., 2012; Wendler et al., 2013), and this cooling is even more pronounced in the simulation with a Pinatubo-like eruption (Fig. 3). We also see strong differences between our two experiments in the 4-year mean of SIC minimum. Exp-2012 shows no positive response of SIC to the volcanic eruption in the Arctic region $\left(0-360^{\circ} \mathrm{E}, 70\right.$ $90^{\circ} \mathrm{N}$; Fig. 6e) and even a slightly negative tendency in local areas (Fig. 5a) in the first four prediction years. On the other hand, we see a significant positive response of maximum SIC in the 2014 initialized experiment in the whole Arctic, which locally reaches values of over $10 \%$ in prediction years $1-4$ (Fig. 5b). This signal decreases slowly and is significant until prediction years 4-7 (Fig. 6f). Screen and Francis (2016) stated that wintertime Arctic warming and sea ice loss is larger during negative PDO phases, which could partly cancel out the cooling effect through the increased aerosol load in the 2012 experiment.

Gagne et al. (2017) stated in their recent study that the sea ice response is dependent on pre-eruption temperature conditions and that a warmer pre-eruption climate leads to a stronger sea ice increase. The results shown in Fig. 6 do not corroborate their findings. In fact, they show a slightly contrary tendency and regions with higher initial sea ice and lower temperature conditions (not shown) react more strongly to the Pinatubo-like eruption. This could be a modeldependent effect or a sampling effect due to the focus on only two initialization times in our study.
It is notable that there is a decreasing trend in all our simulations in the three regions and that the trend is not affected by the Pinatubo-like eruption. If there are increased values of SIC in one experiment (Fig. 6b, c, and f), the difference in SIC values between the Pinatubo and the baseline1 simulations stays nearly constant for all prediction years.

\subsection{Frost days}

Not only mean temperature values are influenced by volcanic aerosol, but also the daily temperature minimum. The Expert Team of Climate Change Indices (ETCCDI; Karl et al., 1999) defines a day as a frost day if the daily minimum temperature is below $0^{\circ} \mathrm{C}$ and the number of frost days (FD) as the sum of those days. Figure 7 shows the anomaly of the number of frost days in our simulations for prediction years 1-4. Through the increased AOD the number of frost days rises, especially over land, in the Northern Hemisphere in most regions. The spatial distribution and magnitude differ between the two initialization times. In exp-2012, the highest significant values are in the Bering Sea, eastern North America, the Nordic Sea, and over China, whereas in the Pinatubo-2014 experiment, the frost days increase most over the whole of North America, Scandinavia, the Nordic Sea, and East Asia. In general, exp-2014 shows a stronger reaction to the volcanic eruption except for the Bering Sea. The spatial distribution of both experiments is in good agreement with the pattern of TAS. The total number of frost days stays enhanced over the whole forecast period and is much higher in the Northern Hemisphere compared to the Southern Hemisphere (not shown).

\subsection{Precipitation}

A critical aspect is the understanding of the volcanic impact on the hydrological cycle. It has been demonstrated that volcanoes modulate the African, Asian, and South American monsoon systems (Liu et al., 2016; Oman et al., 2006), impacting areas that are now home to $\sim 60 \%$ of the world pop- 

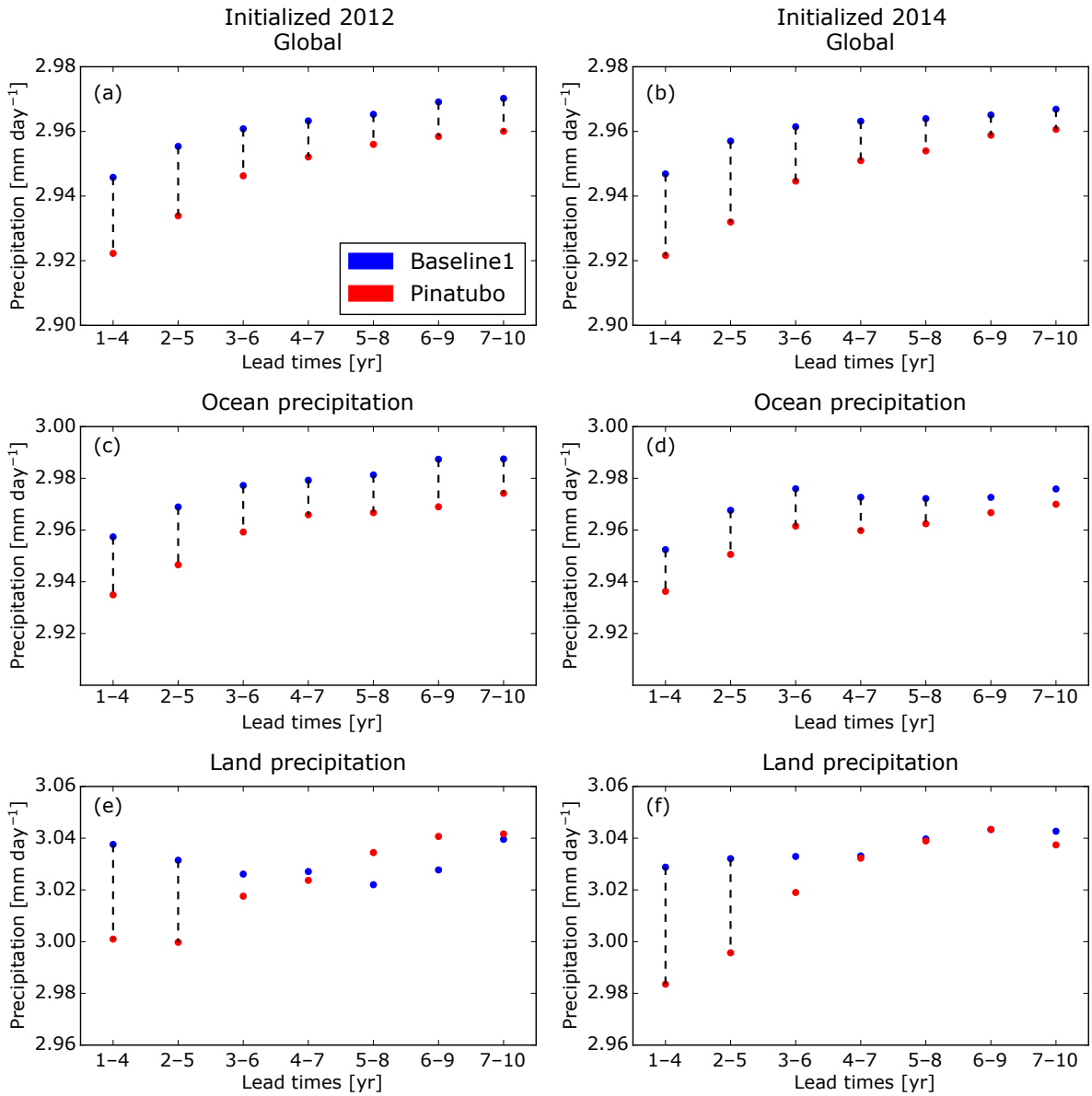

Figure 8. Same as Fig. 2, but for precipitation (PR) and different regions. (a, b) Global mean, (c, d) ocean only, and (e, f) land only. Dashed lines indicate significant differences between the values at the $5 \%$ level.
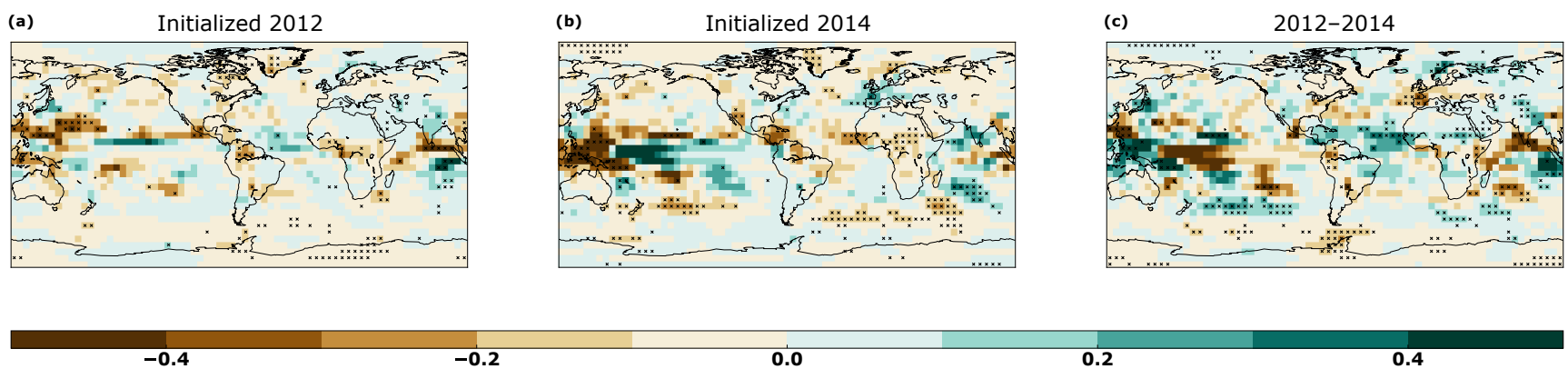

$$
\mathbf{0 . 0}
$$$$
0.2
$$

Figure 9. Same as Fig. 7, but for precipitation (PR) anomalies.

ulation (Lau et al., 2008). We see a clear reduction in global mean precipitation in both experiments (Fig. 8a and b). In the first four prediction years, the magnitude of the reduction is about $0.025 \mathrm{~mm} \mathrm{day}^{-1}$. This behavior is in agreement with previous studies that examined historical volcanic eruptions (Gu and Adler, 2011; Iles et al., 2013; Robock and Mao, 1992). The effect of reduced global mean precipitation due to the Pinatubo-like eruption decreases with pre- diction time, but stays significant for all lead times. In each of the experiments, the drying effect is stronger over land than over the ocean (Fig. 8c-f). Precipitation decreases over land with about $0.04 \mathrm{~mm}$ day $^{-1}$ in the first four prediction years of the 2014 experiment. This is about twice as strong as the maximal decrease over the ocean, but recovers faster to non-eruption values. The precipitation reduction over land is only significant until prediction years $2-5$, whereas the de- 

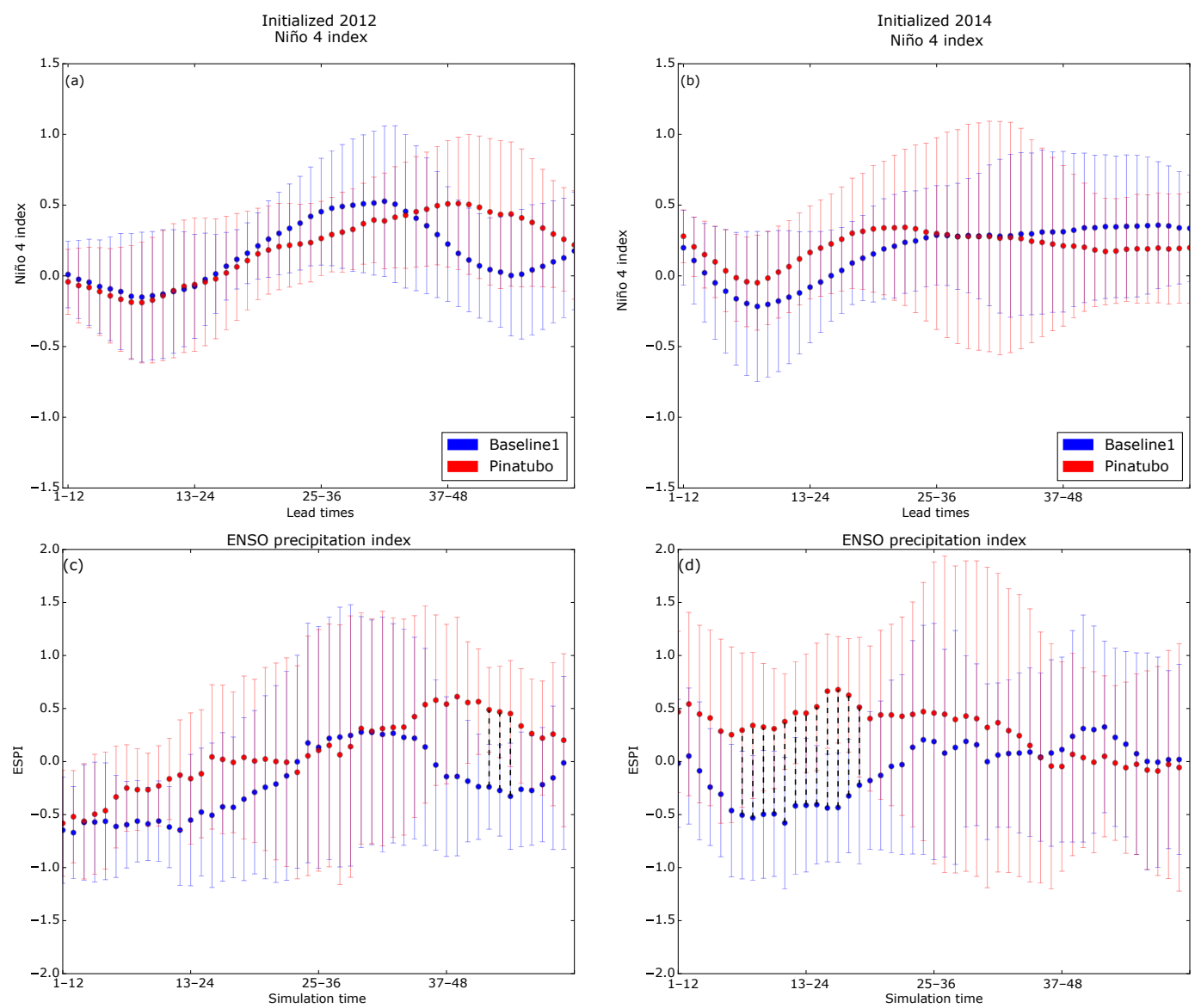

Figure 10. Top row shows the Niño 4 index and bottom row shows the ENSO precipitation index (ESPI) for the first four prediction years calculated as a 12-month running mean to reduce variance. Left (right) column shows the 2012 (2014) initialized experiments. Error bars show the SD of the ensemble and vertical black lines indicate a significant difference.

cline over the ocean remains significant until years $5-8$ in the 2014 experiment or even over the whole simulation period as in the 2012 experiment. While the reduction of land precipitation is a direct feedback to the increased AOD, the precipitation changes over the ocean are a temperature feedback (Iles et al., 2013). Similar behavior has been found in CMIP5 model simulations, although they underestimated the precipitation changes compared to observational data (Iles et al., 2013; Iles and Hegerl, 2014; Paik and Min, 2017). The latter suggests that this underestimation is connected to the underestimated latent heat flux in climate models.

Hence, while there could be some confidence in the general behavior of the post-volcanic changes in the hydrological cycle, the quantitative values of our forecast simulation should be taken with caution. Although the longer-persisting reduction over the ocean is seen in CMIP5 models, it cannot be detected in observations due to the short satellite time period, which covers only two major eruptions (Iles and Hegerl, 2014). The timescale of the precipitation reduction over the ocean is consistent with the response of TAS (Fig. 2). This is in agreement with previous studies (Iles et al., 2013; Joseph and Zeng, 2011).

In the global precipitation maps, we see a reduction of precipitation for both experiments through the volcanic aerosol in large parts, especially over land, in the first four prediction years (Fig. 9). The drying effect is strongest over the tropics, particularly in Southeast Asia, and is even more pronounced in exp-2014. In fact, the tropical precipitation pattern in Southeast Asia and the East Pacific in exp-2014 is very similar to an El Niño response. Recent model studies (Maher et al., 2015; Pausata et al., 2015; Khodri et al., 2017) revealed that volcanic eruptions have a significant impact on ENSO, and there is some ongoing debate about whether a tropical volcanic eruption can trigger an El Niño event (Meehl et al., 2015; Predybaylo et al., 2017; Swingedouw et al., 2017). To further investigate this, we calculated the temperature-based Niño 4 index (Trenberth and Stepaniak, 2001) and the ENSO precipitation index (ESPI; Curtis and Adler, 2000) for both experiments for the first four prediction years (Fig. 10) as 12-month running means to reduce variance. The ensemble initialized in 2014 with a Pinatubo-like eruption shows a ten- 
dency towards El Niño conditions, whereas the baseline1 ensemble favors a weak La Niña condition (Fig. 10b and d). The difference between the two experiments in the ESPI is significant until simulation months 18-30 when both indices come back to neutral conditions. In exp-2012 there is no difference evident in the first three prediction years, but in year 4 the baseline 1 ensemble starts simulating a La Niña phase (Fig. 10a and c) with a significant difference to the Pinatubolike experiment. In general, exp-2014 shows a stronger drying response in the tropical region. In contrast, in this experiment, wetter conditions over Western Europe can be found that do not occur in exp-2012.

\section{Summary and discussion}

In this study, we examined the sensitivity of decadal climate predictions to a tropical volcanic eruption using an artificial Pinatubo-like eruption as stratospheric forcing. We performed two decadal forecasts with different initial conditions, each forecast containing a Pinatubo-like eruption starting in June of the first prediction year, and compared them to the corresponding simulations without a volcanic eruption. We chose the initialization years 2012 and 2014 because they differ in important climate indices like the NAO and the PDO. Other important climate modes like the El NiñoSouthern Oscillation (ENSO) or the Atlantic Multidecadal Oscillation (AMO), which have the potential to influence the volcanic response as well (e.g., Swingedouw et al., 2017, and references therein), are in a similar state in both experiments at the time of initialization (not shown). We have shown that the global near-surface air temperature and precipitation decrease as a response to the volcanic eruption is independent of the initial state of the PDO and the NAO and that the reduction is significant for the whole prediction period in both forecasts. In our experiments, the global mean temperature reduction in the first 4 years following a Pinatubolike eruption is about $0.2 \mathrm{~K}$ and the precipitation is about $0.025 \mathrm{~mm}$ day $^{-1}$. In alignment with previous studies (e.g., Iles and Hegerl, 2014; Paik and Min, 2017) the drying effect is stronger over land than over the ocean, but the drying over land is only significant until prediction years $2-5$.

Pre-eruption climate conditions play an important role for decadal predictions on a regional scale. We found significant regional differences between the two initialization experiments in the variables near-surface air temperature, sea ice area fraction, frost days, and precipitation for the whole forecast period. One of the most substantial differences between the experiments can be found in the predictions of minimum and maximum sea ice area fraction. The volcanic eruption in the 2012 initialized simulation has nearly no effect on the 4-yearly minimum SIC, whereas in exp-2014 we see a significant increase of up to $4 \%$. For maximum SIC, both simulations show increased values, but the increase is concentrated in different regions (2012: the Bering Sea, 2014: the
Nordic Sea). This can be explained partly by the different phase of the PDO; a negative PDO, as in the 2012 initialized experiments, brings colder temperatures to Alaska (Wendler et al., 2013) and strengthens the Arctic wintertime warming (Screen and Francis, 2016). In the 2012 experiment the temperature decrease in the North Pacific basin is nearly constant over the whole prediction period, whereas in 2014 the temperature starts recovering after a few years. Additionally, we see a stronger cooling over Europe and a more pronounced drying in the monsoon region in the first four prediction years and a longer-lasting cooling effect in the North Atlantic in the 2014 initialized simulations. We also see a stronger increase in the number of frost days in most regions - except for the Bering Sea - in this experiment. We could not find a clear link between the different initial states of the NAO and any of these changes.

We note a few caveats and possibilities for improvements to this study. We only investigated the volcanic response to different initial conditions of the NAO and PDO. Therefore, our simulations in this study should be extended with experiments starting with other initial conditions like the recent El Niño year 2015-2016. Another factor currently neglected is the phase of the QBO as it changes due to the postvolcanic atmospheric response (e.g., Thomas et al., 2009) and its self-modulation by strong volcanic eruptions (Aquila et al., 2014). The model (MPI-ESM) in the low-resolution version used in this study is not able to develop its own quasibiennial oscillation (QBO), but the same model with higher vertical resolution shows a predictive skill of the QBO of up to 4 years (Pohlmann et al., 2013). Another aspect is that our results could be model dependent and the analysis should be expanded to a multi-model study. In order to gain a better understanding of the impact of volcanic eruptions on decadal predictions and predictability, a collaboration is planned between the model intercomparison project on the climatic response to volcanic forcing VolMIP (Zanchettin et al., 2016) and the decadal climate prediction project DCPP (Boer et al., 2016). In line with the protocol of the upcoming CMIP6 (Eyring et al., 2016), a set of decadal prediction experiments will be conducted in which, similar to our experiment, the impact of a Pinatubo-like eruption occurring in 2015 will be examined, which provides the unique opportunity to discuss our results in a multi-model framework.

Code and data availability. The model output from all simulations described in this paper will be distributed through the World Data Climate Center at https://www.dkrz.de/up/systems/wdcc and will be freely accessible through this data portal after registration. The code used for our analysis is available in a github repository and can be accessed through the following URL: https://github.com/ illing2005/future-pinatubo.

The Supplement related to this article is available online at https://doi.org/10.5194/esd-9-701-2018-supplement. 
Competing interests. The authors declare that they have no conflict of interest.

Special issue statement. This article is part of the special issue "The Model Intercomparison Project on the climatic response to Volcanic forcing (VolMIP) (ESD/GMD/ACP/CP inter-journal SI)". It is not associated with a conference.

Acknowledgements. We thank Wolfgang Müller and Bereket Berhane whose comments helped to improve this paper. We also thank the three anonymous reviewers for their helpful comments. The research was supported by the German Federal Ministry for Education and Research through the "MiKlip" program (FKZ: 01LP1519B to Sebastian Illing and Christopher Kadow; 01LP1517B to Claudia Timmreck; 01LP1519A to Holger Pohlmann). We acknowledge the use of the European Centre for Medium-Range Weather Forecasts reanalysis data for the initialization (ORAS4, ERA-40, and ERA-Interim). Computations were carried out at the German Climate Computing Centre (DKRZ). Supporting information that may be useful in reproducing the authors' work is available from the authors upon request (sebastian.illing@met.fu-berlin.de).

Edited by: Govindasamy Bala

Reviewed by: three anonymous referees

\section{References}

Ammann, C. M. and Naveau, P.: Statistical analysis of tropical explosive volcanism occurrences over the last 6 centuries: STATISTICS OF TROPICAL EXPLOSIVE VOLCANISM, Geophys. Res. Lett., 30, https://doi.org/10.1029/2002GL016388, 2003.

Aquila, V., Garfinkel, C. I., Newman, P. A., Oman, L. D., and Waugh, D. W.: Modifications of the quasi-biennial oscillation by a geoengineering perturbation of the stratospheric aerosol layer, Geophys. Res. Lett., 41, 1738-1744, https://doi.org/10.1002/2013GL058818, 2014.

Balmaseda, M. A., Mogensen, K., and Weaver, A. T.: Evaluation of the ECMWF ocean reanalysis system ORAS4, Q. J. Roy. Meteor. Soc., 139, 1132-1161, https://doi.org/10.1002/qj.2063, 2013.

Bethke, I., Outten, S., Otterå, O. H., Hawkins, E., Wagner, S., Sigl, M., and Thorne, P.: Potential volcanic impacts on future climate variability, Nat. Clim. Change, 7, 799-805, https://doi.org/10.1038/nclimate3394, 2017.

Bittner, M., Schmidt, H., Timmreck, C., and Sienz, F.: Using a large ensemble of simulations to assess the Northern Hemisphere stratospheric dynamical response to tropical volcanic eruptions and its uncertainty, Geophys. Res. Lett., 43, 93249332, https://doi.org/10.1002/2016GL070587, 2016.

Boer, G. J., Smith, D. M., Cassou, C., Doblas-Reyes, F., Danabasoglu, G., Kirtman, B., Kushnir, Y., Kimoto, M., Meehl, G. A., Msadek, R., Mueller, W. A., Taylor, K. E., Zwiers, F., Rixen, M., Ruprich-Robert, Y., and Eade, R.: The Decadal Climate Prediction Project (DCPP) contribution to CMIP6, Geosci. Model Dev., 9, 3751-3777, https://doi.org/10.5194/gmd-9-3751-2016, 2016.
Curtis, S. and Adler, R.: ENSO Indices Based on Patterns of Satellite-Derived Precipitation, J. Climate, 13, 2786-2793, https://doi.org/10.1175/15200442(2000)013<2786:EIBOPO>2.0.CO;2, 2000.

Dee, D. P., Uppala, S. M., Simmons, A. J., Berrisford, P., Poli, P., Kobayashi, S., Andrae, U., Balmaseda, M. A., Balsamo, G., Bauer, P., Bechtold, P., Beljaars, A. C. M., van de Berg, L., Bidlot, J., Bormann, N., Delsol, C., Dragani, R., Fuentes, M., Geer, A. J., Haimberger, L., Healy, S. B., Hersbach, H., Hólm, E. V., Isaksen, L., Kållberg, P., Köhler, M., Matricardi, M., McNally, A. P., Monge-Sanz, B. M., Morcrette, J.-J., Park, B.K., Peubey, C., de Rosnay, P., Tavolato, C., Thépaut, J.-N., and Vitart, F.: The ERA-Interim reanalysis: configuration and performance of the data assimilation system, Q. J. Roy. Meteor. Soc., 137, 553-597, https://doi.org/10.1002/qj.828, 2011.

Ding, Y., Carton, J. A., Chepurin, G. A., Stenchikov, G., Robock, A., Sentman, L. T., and Krasting, J. P.: Ocean response to volcanic eruptions in Coupled Model Intercomparison Project 5 simulations, J. Geophys. Res.-Oceans, 119, 5622-5637, https://doi.org/10.1002/2013jc009780, 2014.

Doblas-Reyes, F. J., Andreu-Burillo, I., Chikamoto, Y., GarcíaSerrano, J., Guemas, V., Kimoto, M., Mochizuki, T., Rodrigues, L. R. L., and van Oldenborgh, G. J.: Initialized nearterm regional climate change prediction, Nat. Commun., 4, 1715, https://doi.org/10.1038/ncomms2704, 2013.

Eyring, V., Bony, S., Meehl, G. A., Senior, C. A., Stevens, B., Stouffer, R. J., and Taylor, K. E.: Overview of the Coupled Model Intercomparison Project Phase 6 (CMIP6) experimental design and organization, Geosci. Model Dev., 9, 1937-1958, https://doi.org/10.5194/gmd-9-1937-2016, 2016.

Gagné, M.-È., Kirchmeier-Young, M. C., Gillett, N. P., and Fyfe, J. C.: Arctic sea ice response to the eruptions of Agung, El Chichón and Pinatubo: Arctic sea ice response to volcanoes, J. Geophys. Res.-Atmos., 122, 8071-8078, https://doi.org/10.1002/2017JD027038, 2017.

Giorgetta, M. A., Jungclaus, J., Reick, C. H., Legutke, S., Bader, J., Böttinger, M., Brovkin, V., Crueger, T., Esch, M., Fieg, K., Glushak, K., Gayler, V., Haak, H., Hollweg, H.D., Ilyina, T., Kinne, S., Kornblueh, L., Matei, D., Mauritsen, T., Mikolajewicz, U., Mueller, W., Notz, D., Pithan, F., Raddatz, T., Rast, S., Redler, R., Roeckner, E., Schmidt, H., Schnur, R., Segschneider, J., Six, K. D., Stockhause, M., Timmreck, C., Wegner, J., Widmann, H., Wieners, K.-H., Claussen, M., Marotzke, J., and Stevens, B.: Climate and carbon cycle changes from 1850 to 2100 in MPI-ESM simulations for the Coupled Model Intercomparison Project phase 5: Climate Changes in MPI-ESM, J. Adv. Model. Earth Sy., 5, 572-597, https://doi.org/10.1002/jame.20038, 2013.

Goddard, L., Kumar, A., Solomon, A., Smith, D., Boer, G., Gonzalez, P., Kharin, V., Merryfield, W., Deser, C., Mason, S. J., Kirtman, B. P., Msadek, R., Sutton, R., Hawkins, E., Fricker, T., Hegerl, G., Ferro, C. A. T., Stephenson, D. B., Meehl, G. A., Stockdale, T., Burgman, R., Greene, A. M., Kushnir, Y., Newman, M., Carton, J., Fukumori, I., and Delworth, T.: A verification framework for interannual-todecadal predictions experiments, Clim. Dynam., 40, 245-272, https://doi.org/10.1007/s00382-012-1481-2, 2013.

Gu, G. and Adler, R. F.: Precipitation and Temperature Variations on the Interannual Time Scale: Assessing the Impact 
of ENSO and Volcanic Eruptions, J. Climate, 24, 2258-2270, https://doi.org/10.1175/2010JCLI3727.1, 2011.

Guemas, V., Doblas-Reyes, F. J., Lienert, F., Soufflet, Y., and $\mathrm{Du}, \mathrm{H}$.: Identifying the causes of the poor decadal climate prediction skill over the North Pacific, J. Geophys. Res., 117, D20111, https://doi.org/10.1029/2012JD018004, 2012.

Houghton, J. T., Meiro Filho, L. G., Callander, B. A., Harris, N., Kattenburg, A., and Maskell, K.: Climate Change 1995: The Science of Climate Change: Contribution of Working Group I to the Second Assessment Report of the Intergovernmental Panel on Climate Change, Cambridge University Press, available at: https://books.google.com/books/about/Climate_Change_1995_ The_Science_of_Clima.html?hl=\&id=849SAQAACAAJ, 1996.

Iles, C. E. and Hegerl, G. C.: The global precipitation response to volcanic eruptions in the CMIP5 models, Environ. Res. Lett., 9, 104012, https://doi.org/10.1088/1748-9326/9/10/104012, 2014.

Iles, C. E., Hegerl, G. C., Schurer, A. P., and Zhang, X.: The effect of volcanic eruptions on global precipitation: VOLCANOES AND PRECIPITATION, J. Geophys. Res.-Atmos., 118, 87708786, https://doi.org/10.1002/jgrd.50678, 2013.

Illing, S., Kadow, C., Kunst, O., and Cubasch, U.: MurCSS: A Tool for Standardized Evaluation of Decadal Hindcast Systems, Journal of Open Research Software, 2, 245, https://doi.org/10.5334/jors.bf, 2014.

Joseph, R. and Zeng, N.: Seasonally Modulated Tropical Drought Induced by Volcanic Aerosol, J. Climate, 24, 2045-2060, https://doi.org/10.1175/2009JCLI3170.1, 2011.

Jungclaus, J. H., Fischer, N., Haak, H., Lohmann, K., Marotzke, J., Matei, D., Mikolajewicz, U., Notz, D., and von Storch, J. S.: Characteristics of the ocean simulations in the Max Planck Institute Ocean Model (MPIOM) the ocean component of the MPI-Earth system model: Mpiom CMIP5 Ocean Simulations, J. Adv. Model. Earth Sy., 5, 422-446, https://doi.org/10.1002/jame.20023, 2013.

Kadow, C., Illing, S., Kunst, O., Rust, H. W., Pohlmann, H., Müller, W. A., and Cubasch, U.: Evaluation of forecasts by accuracy and spread in the MiKlip decadal climate prediction system, Meteorol. Z., 25, 631-643, https://doi.org/10.1127/metz/2015/0639, 2016.

Karl, T. R., Nicholls, N., and Ghazi, A.: CLIVAR/GCOS/WMO Workshop on Indices and Indicators for Climate Extremes Workshop Summary, in: Weather and Climate Extremes, 3-7, 1999.

Khodri, M., Izumo, T., Vialard, J., Janicot, S., Cassou, C., Lengaigne, M., Mignot, J., Gastineau, G., Guilyardi, E., Lebas, N., Robock, A., and McPhaden, M. J.: Tropical explosive volcanic eruptions can trigger El Niño by cooling tropical Africa, Nat. Commun., 8, 778, https://doi.org/10.1038/s41467017-00755-6, 2017.

Kim, H.-M., Webster, P. J., and Curry, J. A.: Evaluation of short-term climate change prediction in multi-model CMIP5 decadal hindcasts: MULTI-MODEL CMIP5 DECADAL PREDICTIONS, Geophys. Res. Lett., 39, https://doi.org/10.1029/2012GL051644, 2012.

Kirchner, I., Stenchikov, G. L., Graf, H.-F., Robock, A., and Antuña, J. C.: Climate model simulation of winter warming and summer cooling following the 1991 Mount Pinatubo volcanic eruption, J. Geophys. Res., 104, 19039-19055, https://doi.org/10.1029/1999JD900213, 1999.
Kirtman, B., Power, S.B., Adedoyin, A.J., Boer, G.J., Bojariu, R., Camilloni, I., Doblas-Reyes, F., Fiore, A.M., Kimoto, M., Meehl, G., and Prather, M.: Near-term climate change: Projections and predictability, Climate Change 2013: The Physical Science Basis, edited by: Stocker, T. F., Qin, D., Plattner, G.-K., Tignor, M., Allen, S. K., Boschung, J., Nauels, A., Xia, Y., Bex, V., and Midgley, P. M., Cambridge University Press, https://doi.org/10.1017/CBO9781107415324, 953-1028, 2013.

Lau, K., Ramanathan, V., Wu, G., Li, Z., Tsay, S. C., Hsu, C., Sikka, R., Holben, B., Lu, D., Tartari, G., Chin, M., Koudelova, P., Chen, H., Ma, Y., Huang, J., Taniguchi, K., and Zhang, R.: The Joint Aerosol-Monsoon Experiment: A New Challenge for Monsoon Climate Research, B. Am. Meteorol. Soc., 89, 369-384, https://doi.org/10.1175/BAMS-89-3-369, 2008.

Liu, F., Chai, J., Wang, B., Liu, J., Zhang, X., and Wang, Z.: Global monsoon precipitation responses to large volcanic eruptions, Sci. Rep.-UK, 6, 24331, https://doi.org/10.1038/srep24331, 2016.

Maher, N., McGregor, S., England, M. H., and Gupta, A. S.: Effects of volcanism on tropical variability: EFFECTS OF VOLCANISM, Geophys. Res. Lett., 42, 6024-6033, https://doi.org/10.1002/2015GL064751, 2015.

Mantua, N. J. and Hare, S. R.: The Pacific Decadal Oscillation, J. Oceanogr., 58, 35-44, https://doi.org/10.1023/A:1015820616384, 2002.

Marotzke, J., Müller, W. A., Vamborg, F. S. E., Becker, P., Cubasch, U., Feldmann, H., Kaspar, F., Kottmeier, C., Marini, C., Polkova, I., Prömmel, K., Rust, H. W., Stammer, D., Ulbrich, U., Kadow, C., Köhl, A., Kröger, J., Kruschke, T., Pinto, J. G., Pohlmann, H., Reyers, M., Schröder, M., Sienz, F., Timmreck, C., and Ziese, M.: MiKlip: A National Research Project on Decadal Climate Prediction, B. Am. Meteorol. Soc., 97, 23792394, https://doi.org/10.1175/bams-d-15-00184.1, 2016.

Marshall, A. G., Scaife, A. A., and Ineson, S.: Enhanced Seasonal Prediction of European Winter Warming following Volcanic Eruptions, J. Climate, 22, 6168-6180, https://doi.org/10.1175/2009JCLI3145.1, 2009.

Matei, D., Baehr, J., Jungclaus, J. H., Haak, H., Müller, W. A., and Marotzke, J.: Multiyear prediction of monthly mean Atlantic meridional overturning circulation at $26.5^{\circ} \mathrm{N}$, Science, 335, 7679, https://doi.org/10.1126/science.1210299, 2012.

Mauritsen, T., Stevens, B., Roeckner, E., Crueger, T., Esch, M., Giorgetta, M., Haak, H., Jungclaus, J., Klocke, D., Matei, D., Mikolajewicz, U., Notz, D., Pincus, R., Schmidt, H., and Tomassini, L.: Tuning the climate of a global model, J. Adv. Model. Earth Sy., 4, https://doi.org/10.1029/2012MS000154, 2012.

Meehl, G. A., Goddard, L., Murphy, J., Stouffer, R. J., Boer, G., Danabasoglu, G., Dixon, K., Giorgetta, M. A., Greene, A. M., Hawkins, E., Hegerl, G., Karoly, D., Keenlyside, N., Kimoto, M., Kirtman, B., Navarra, A., Pulwarty, R., Smith, D., Stammer, D., and Stockdale, T.: Decadal Prediction: Can It Be Skillful?, B. Am. Meteorol. Soc., 90, 1467-1485, https://doi.org/10.1175/2009BAMS2778.1, 2009.

Meehl, G. A., Teng, H., Maher, N., and England, M. H.: Effects of the Mount Pinatubo eruption on decadal climate prediction skill of Pacific sea surface temperatures: PINATUBO AND DECADAL PREDICTION SKILL, Geophys. Res. Lett., 42, 10840-10846, https://doi.org/10.1002/2015GL066608, 2015. 
Ménégoz, M., Cassou, C., Swingedouw, D., Bretonnière, P.A., and Doblas-Reyes, F.: Role of the Atlantic Multidecadal Variability in modulating the climate response to a Pinatubo-like volcanic eruption, Clim. Dynam., 0930-7575, https://doi.org/10.1007/s00382-017-3986-1, 2017.

metoffice.gov: Decadal forecast, Met Office, http://www.metoffice. gov.uk/research/climate/seasonal-to-decadal/long-range/ decadal-fc, last access: 12 October 2017, 2017.

Niemeier, U., Timmreck, C., Graf, H.-F., Kinne, S., Rast, S., and Self, S.: Initial fate of fine ash and sulfur from large volcanic eruptions, Atmos. Chem. Phys., 9, 9043-9057, https://doi.org/10.5194/acp-9-9043-2009, 2009.

Oman, L., Robock, A., Stenchikov, G. L., and Thordarson, T.: High-latitude eruptions cast shadow over the African monsoon and the flow of the Nile, Geophys. Res. Lett., 33, https://doi.org/10.1029/2006gl027665, 2006.

Ortega, P., Lehner, F., Swingedouw, D., Masson-Delmotte, V., Raible, C. C., Casado, M., and Yiou, P.: A model-tested North Atlantic Oscillation reconstruction for the past millennium, Nature, 523, 71-74, https://doi.org/10.1038/nature14518, 2015.

Overland, J. E., Wang, M., Wood, K. R., Percival, D. B., and Bond, N. A.: Recent Bering Sea warm and cold events in a 95 year context, Deep-Sea Res. Pt. II, 65, 6-13, https://doi.org/10.1016/j.dsr2.2012.02.013, 2012.

Paik, S. and Min, S.-K.: Climate responses to volcanic eruptions assessed from observations and CMIP5 multi-models, Clim. Dynam., 48, 1017-1030, https://doi.org/10.1007/s00382-016-31254, 2017.

Pausata, F. S. R., Chafik, L., Caballero, R., and Battisti, D. S.: Impacts of high-latitude volcanic eruptions on ENSO and AMOC, P. Natl. Acad. Sci. USA, 112, 13784-13788, https://doi.org/10.1073/pnas.1509153112, 2015.

Pohlmann, H., Müller, W. A., Kulkarni, K., Kameswarrao, M., Matei, D., Vamborg, F. S. E., Kadow, C., Illing, S., and Marotzke, J.: Improved forecast skill in the tropics in the new MiKlip decadal climate predictions, Geophys. Res. Lett., 40, 5798-5802, https://doi.org/10.1002/2013gl058051, 2013.

Predybaylo, E., Stenchikov, G. L., Wittenberg, A. T., and Zeng, F.: Impacts of a Pinatub Size Volcanic Eruption on ENSO, J. Geophys. Res.-Atmos., 122, 925947, https://doi.org/10.1002/2016JD025796, 2017.

Robock, A.: Volcanic eruptions and climate, Rev. Geophys., 38, 191-219, https://doi.org/10.1029/1998RG000054, 2000.

Robock, A. and Mao, J.: Winter warming from large volcanic eruptions, Geophys. Res. Lett., 19, 2405-2408, https://doi.org/10.1029/92GL02627, 1992.

Screen, J. A. and Francis, J. A.: Contribution of seaice loss to Arctic amplification is regulated by Pacific Ocean decadal variability, Nat. Clim. Change, 6, 856-860, https://doi.org/10.1038/nclimate3011, 2016.

Self, S.: The effects and consequences of very large explosive volcanic eruptions, Philos. T. R. Soc. S.-A, 364, 2073-2097, https://doi.org/10.1098/rsta.2006.1814, 2006.

Smith, D. M., Cusack, S., Colman, A. W., Folland, C. K., Harris, G. R., and Murphy, J. M.: Improved surface temperature prediction for the coming decade from a global climate model, Science, 317, 796-799, https://doi.org/10.1126/science.1139540, 2007.
Smith, D. M., Scaife, A. A., Boer, G. J., Caian, M., DoblasReyes, F. J., Guemas, V., Hawkins, E., Hazeleger, W., Hermanson, L., Ho, C. K., Ishii, M., Kharin, V., Kimoto, M., Kirtman, B., Lean, J., Matei, D., Merryfield, W. J., Müller, W. A., Pohlmann, H., Rosati, A., Wouters, B., and Wyser, K.: Realtime multi-model decadal climate predictions, Clim. Dynam., 41, 2875-2888, https://doi.org/10.1007/s00382-012-1600-0, 2013.

Stenchikov, G. L., Kirchner, I., Robock, A., Graf, H.-F., Antuña, J. C., Grainger, R. G., Lambert, A., and Thomason, L.: Radiative forcing from the 1991 Mount Pinatubo volcanic eruption, J. Geophys. Res.-Atmos., 103, 13837-13857, https://doi.org/10.1029/98jd00693, 1998.

Stevens, B., Giorgetta, M., Esch, M., Mauritsen, T., Crueger, T., Rast, S., Salzmann, M., Schmidt, H., Bader, J., Block, K., Brokopf, R., Fast, I., Kinne, S., Kornblueh, L., Lohmann, U., Pincus, R., Reichler, T., and Roeckner, E.: Atmospheric component of the MPI-M Earth System Model: ECHAM6: ECHAM6, J. Adv. Model. Earth Sy., 5, 146-172, https://doi.org/10.1002/jame.20015, 2013.

Stier, P., Feichter, J., Kinne, S., Kloster, S., Vignati, E., Wilson, J., Ganzeveld, L., Tegen, I., Werner, M., Balkanski, Y., Schulz, M., Boucher, O., Minikin, A., and Petzold, A.: The aerosol-climate model ECHAM5-HAM, Atmos. Chem. Phys., 5, 1125-1156, https://doi.org/10.5194/acp-5-1125-2005, 2005.

Stolzenberger, S., Glowienka-Hense, R., Spangehl, T., Schröder, M., Mazurkiewicz, A., and Hense, A.: Revealing skill of the MiKlip decadal prediction system by threedimensional probabilistic evaluation, Meteorol. Z., 25, 657-671, https://doi.org/10.1127/metz/2015/0606, 2016.

Swingedouw, D., Mignot, J., Ortega, P., Khodri, M., Menegoz, M., Cassou, C., and Hanquiez, V.: Impact of explosive volcanic eruptions on the main climate variability modes, Global Planet. Change, 150, 24-45, https://doi.org/10.1016/j.gloplacha.2017.01.006, 2017.

Thomas, M. A., Giorgetta, M. A., Timmreck, C., Graf, H.-F., and Stenchikov, G.: Simulation of the climate impact of Mt. Pinatubo eruption using ECHAM5 - Part 2: Sensitivity to the phase of the QBO and ENSO, Atmos. Chem. Phys., 9, 3001-3009, https://doi.org/10.5194/acp-9-3001-2009, 2009.

Thompson, D. W. J., Wallace, J. M., Jones, P. D., and Kennedy, J. J.: Identifying Signatures of Natural Climate Variability in Time Series of Global-Mean Surface Temperature: Methodology and Insights, J. Climate, 22, 6120-6141, https://doi.org/10.1175/2009JCLI3089.1, 2009.

Timmreck, C.: Modeling the climatic effects of large explosive volcanic eruptions, WIREs Clim. Change, 3, 545-564, https://doi.org/10.1002/wcc.192, 2012.

Timmreck, C., Pohlmann, H., Illing, S., and Kadow, C.: The impact of stratospheric volcanic aerosol on decadal-scale climate predictions: Volcanoes and Decadal Predictability, Geophys. Res. Lett., 43, 834-842, https://doi.org/10.1002/2015GL067431, 2016.

Toohey, M., Krüger, K., Bittner, M., Timmreck, C., and Schmidt, H.: The impact of volcanic aerosol on the Northern Hemisphere stratospheric polar vortex: mechanisms and sensitivity to forcing structure, Atmos. Chem. Phys., 14, 13063-13079, https://doi.org/10.5194/acp-14-13063-2014, 2014.

Trenberth, K. E. and Stepaniak, D. P.: Indices of El Niño Evolution, J. Climate, 14, 1697-1701, https://doi.org/10.1175/15200442(2001)014<1697:LIOENO>2.0.CO;2, 2001. 
Vamborg, F., Illing, S., Kadow, C., Tiedje, B., Paxian, A., Müller, W., Pohlmann, H., Grieger, J., Pasternack, A., Feldmann, H., and Marotzke, J.: Decadal Forecast for 2017-2026, FONA MiKlip, https://www.fona-miklip.de/decadal-climate-prediction-system/ decadal-forecast-for-2017-2026/, last access: 12 October 2017, 2017.

Visbeck, M. H., Hurrell, J. W., Polvani, L., and Cullen, H. M.: The North Atlantic Oscillation: past, present, and future, P. Natl. Acad. Sci. USA, 98, 12876-12877, https://doi.org/10.1073/pnas.231391598, 2001.

Wendler, G.: The First Decade of the New Century: A Cooling Trend for Most of Alaska, The Open Atmospheric Science Journal, 6, 111-116, https://doi.org/10.2174/1874282301206010111, 2012.

Wendler, G., Chen, L., and Moore, B.: Recent sea ice increase and temperature decrease in the Bering Sea area, Alaska, Theor. Appl. Climatol., 117, 393-398, https://doi.org/10.1007/s00704013-1014-x, 2013.
Wilks, D. S.: Statistical Methods in the Atmospheric Sciences, Academic Press, available at: https://books.google.com/books/ about/Statistical_Methods_in_the_Atmospheric_ S.html?hl= \&id=IJuCVtQ0ySIC, 2011.

Zanchettin, D., Bothe, O., Graf, H. F., Lorenz, S. J., Luterbacher, J., Timmreck, C., and Jungclaus, J. H.: Background conditions influence the decadal climate response to strong volcanic eruptions, J. Geophys. Res.-Atmos., 118, 4090-4106, https://doi.org/10.1002/jgrd.50229, 2013.

Zanchettin, D., Khodri, M., Timmreck, C., Toohey, M., Schmidt, A., Gerber, E. P., Hegerl, G., Robock, A., Pausata, F. S. R., Ball, W. T., Bauer, S. E., Bekki, S., Dhomse, S. S., LeGrande, A. N., Mann, G. W., Marshall, L., Mills, M., Marchand, M., Niemeier, U., Poulain, V., Rozanov, E., Rubino, A., Stenke, A., Tsigaridis, K., and Tummon, F.: The Model Intercomparison Project on the climatic response to Volcanic forcing (VolMIP): experimental design and forcing input data for CMIP6, Geosci. Model Dev., 9, 2701-2719, https://doi.org/10.5194/gmd-9-2701-2016, 2016. 